\title{
IMPROVEMENT OF ADAPTABILITY TO FABRICATION AND WELDING PROPERTIES OF ELECTRODES FOR TIN BRONZE WELDING AND SURFACING
}

\author{
T.B. MAJDANCHUK and N.V. SKORINA \\ E.O. Paton Electric Welding Institute, NASU \\ 11 Bozhenko Str., 03680, Kiev, Ukraine. E-mail: office@paton.kiev.ua
}

\begin{abstract}
The paper gives the results of investigation of the influence of various kinds of alkali-silicate binder on adaptability to fabrication and welding properties of coated electrodes for tin bronze welding and surfacing. Both standard (sodium, potassium and mixed) and test lithium-containing liquid glasses were used during investigations. A procedure developed at PWI was used to determine plastic properties of electrode coating mixture and to assess the strength and hygroscopicity of electrode coatings. Studies of welding-technological and sanitary-hygienic properties of test electrodes were also performed. This resulted in selection of optimum kind of liquid glass, the most suitable for manufacture of coated electrodes for tin bronze welding and surfacing. 8 Ref., 4 Tables, 5 Figures.
\end{abstract}

$\boldsymbol{K} \boldsymbol{e} \boldsymbol{y} \boldsymbol{w} \boldsymbol{O} \boldsymbol{r} \boldsymbol{d} \boldsymbol{s}:$ tin bronze, surfacing, coated electrodes, liquid glass, adaptability to fabrication

At present tin bronzes are becoming widely applied in components and friction mechanisms subjected to increased wear in different operation conditions, that is greatly promoted by a favourable combination of their physical and technological properties. Various welding processes are used in order to save this expensive non-ferrous metal. The simplest and least expensive method is manual arc welding (surfacing) by coated electrodes. Ukraine has no production of coated electrodes for welding and surfacing, and for repairing casting defects of tin bronzes, and the cost of foreign electrodes is high, that is why PWI developed electrodes of ANBO grade [1, 2].

The coating has specific composition, associated with presence of chemically active towards the binder (liquid glass) components of sodium salts (hexafluorosilicate, hexafluoraluminate and fluroride) in it, as well as non-traditional metal components (tin, copper-phosphorus powders). In this connection, it is necessary to per- form research and selection of optimum kind of alkali-silicate binder, the properties of which largely determine the technology of manufacturing, quality and service properties of electrodes.

Standard (sodium, potassium and mixed sodium and potassium) and test lithium-containing liquid glasses were prepared for investigations, which give unique properties to some electrode types [3]. Their physico-chemical characteristics are given in Table 1.

Testing included determination of plastic properties of electrode coating mixtures, assessment of strength and hygroscopicity of electrode coatings; checking welding-technological properties and determination of sanitary-hygienic properties of electrodes.

Coating mixture plasticity. Plasticity properties of coating mixtures were evaluated using procedures and instruments developed at PWI [4--6]. Coating mixture fluidity was determined with capillary viscosimeter OB-1435 by its extrusion through a die of $4 \mathrm{~mm}$ diameter and $40 \mathrm{~mm}$ length at minimum $\left(1 \mathrm{~cm}^{3} / \mathrm{s}\right)$ and maximum $\left(10 \mathrm{~cm}^{3} / \mathrm{s}\right)$ volume flows. Here, pressure and

Table 1. Physico-chemical parameters of liquid glasses used at testing

\begin{tabular}{|c|c|c|c|c|c|c|c|}
\hline \multirow{2}{*}{ Glass type } & \multirow{2}{*}{$\begin{array}{l}\text { Density } \rho \\
\mathrm{g} / \mathrm{cm}^{3}\end{array}$} & \multirow{2}{*}{$\begin{array}{c}\text { Viscocity } \eta, \\
\text { MPa.s, at } 20{ }^{\circ} \mathrm{C}\end{array}$} & \multicolumn{4}{|c|}{ Composition, wt.\% } & \multirow{2}{*}{ Module } \\
\hline & & & $\mathrm{SiO}_{2}$ & $\mathrm{Li}_{2} \mathrm{O}$ & $\mathrm{Na}_{2} \mathrm{O}$ & $\mathrm{K}_{2} \mathrm{O}$ & \\
\hline $\mathrm{Na}$ & 1.430 & 392 & 29.03 & - & 8.83 & 2.15 & 2.93 \\
\hline $\mathrm{Na}-\mathrm{K}$ & 1.435 & 606 & 28.80 & - & 6.94 & 4.56 & 2.99 \\
\hline $\mathrm{K}-\mathrm{Na}$ & 1.428 & 304 & 27.85 & - & 4.00 & 8.79 & 2.94 \\
\hline K & 1.415 & 260 & 26.92 & - & 0.03 & 13.78 & 3.05 \\
\hline $\mathrm{Na}-\mathrm{Li}$ & 1.396 & 526 & 30.19 & 2.69 & 0.99 & 5.17 & 2.73 \\
\hline $\mathrm{K}-\mathrm{Li}$ & 1.421 & 554 & 27.93 & 1.42 & 0.94 & 10.67 & 2.65 \\
\hline $\mathrm{Li}$ & 1.258 & 287 & 25.08 & 3.19 & - & - & 3.91 \\
\hline
\end{tabular}






Figure 1. Curves of extrusion of ANBO electrode coating mixture prepared with different kinds of binders: $a-Q=$ $=1 ; b-10 \mathrm{~cm}^{3} / \mathrm{s}$

nature of coating mixture extrusion were recorded. Strength (hardness) of raw coating mixture were assessed by the value of plastic strength measured on conical autoplastometer OB-2059. The coating mixture, which at the same fluidity has higher values of plastic strength or at equivalent plastic strength, is characterized by lower extrusion pressures is believed to be more ductile.

Moreover, preservation of plastic state of coating mixture in time (up to $3 \mathrm{~h}$ ) required for its processing was checked by the nature and magnitude of extrusion pressure.

Results of evaluation of plasticity of coating mixtures, made with application of various binders, are shown in Table 2 and Figure 1.

As follows from these data, the binders influence the plasticity of electrode coating mixtures. Coating mixtures, prepared with four standard $\mathrm{Na}-\mathrm{K}$ liquid glasses, are characterized by smooth and stable extrusion both at minimum and at maximum flow at practically the same extrusion pressures $\left(17-18.5 \mathrm{MPa}\right.$ at $Q=1 \mathrm{~cm}^{2} / \mathrm{s}$ and 23-25 $\mathrm{MPa}$ at $\left.Q=10 \mathrm{~cm}^{3} / \mathrm{s}\right)$. An essential difference in strength properties of coating mixtures is found, however. The highest plastic strength of coating mixture is reached at application of $\mathrm{K}$ and $\mathrm{K}-\mathrm{Na}$ liquid glasses; the lowest value of plas-

Table 2. Plastic properties of coating mixtures

\begin{tabular}{||c|c|c|c|c||}
\hline \multirow{2}{*}{ Glass type } & \multirow{2}{*}{$\begin{array}{c}\text { Glass dose, } \\
\%\end{array}$} & $\begin{array}{c}\text { Plastic } \\
\text { strength } \\
P_{m} \cdot 10^{-5}, \mathrm{~Pa}\end{array}$ & $\begin{array}{c}\text { Extrusion pressure } P_{\text {ex }}, \\
\text { MPa, at consumption } Q, \\
\mathrm{~cm}^{3} / \mathrm{s}\end{array}$ \\
\cline { 4 - 5 } & & 5.8 & 1 & 10 \\
\hline $\mathrm{Na}$ & 28 & 3.45 & 17.5 & 24.5 \\
\hline $\mathrm{Na}-\mathrm{K}$ & 28 & 16.7 & 17 & 25 \\
\hline $\mathrm{K}-\mathrm{Na}$ & 28.2 & 18.0 & 18.5 & 23 \\
\hline $\mathrm{K}$ & 28 & $\sim 0.4$ & 9 & 16 \\
\hline $\mathrm{Na}-\mathrm{Li}$ & 28 & $\sim 0.4$ & 9 & 15 \\
\hline $\mathrm{K}-\mathrm{Li}$ & 28 & 63.2 & 13.5 & 18.5 \\
\hline $\mathrm{Li}$ & 29 & \multicolumn{3}{|l}{} \\
\hline
\end{tabular}

tic strength is found in coating mixtures made from $\mathrm{Na}$ and $\mathrm{Na}-\mathrm{K}$ binders. A similar phenomenon is observed in electrode coating mixtures designed for welding steels, and is attributable to differences in size and degree of hydration of potassium and sodium cations.

Compared to $\mathrm{Na}-\mathrm{K}$ binders, purely lithium liquid glass provides the most favourable combination of strength and extrusion properties of coating mixtures (plastic strength reaches $63 \cdot 10^{5} \mathrm{~Pa}$ at lower extrusion pressures).

Mixtures of $\mathrm{Li}-\mathrm{Na}$ and $\mathrm{Li}-\mathrm{K}$ liquid glasses at their equivalent dose form less consistent coating mixtures (lower plastic strength and extrusion pressure) that is, probably, related to smaller modulus of the above-mentioned silicates.

Coating mixtures, made of the studied $\mathrm{Na}-\mathrm{K}$ binders, do not harden with time (Figure 2). Extrusion pressure practically does not change during $2 \mathrm{~h}$. Li-containing liquid glasses unambiguously change the consistency of coating mixtures at storage. So, in coating mixture, made

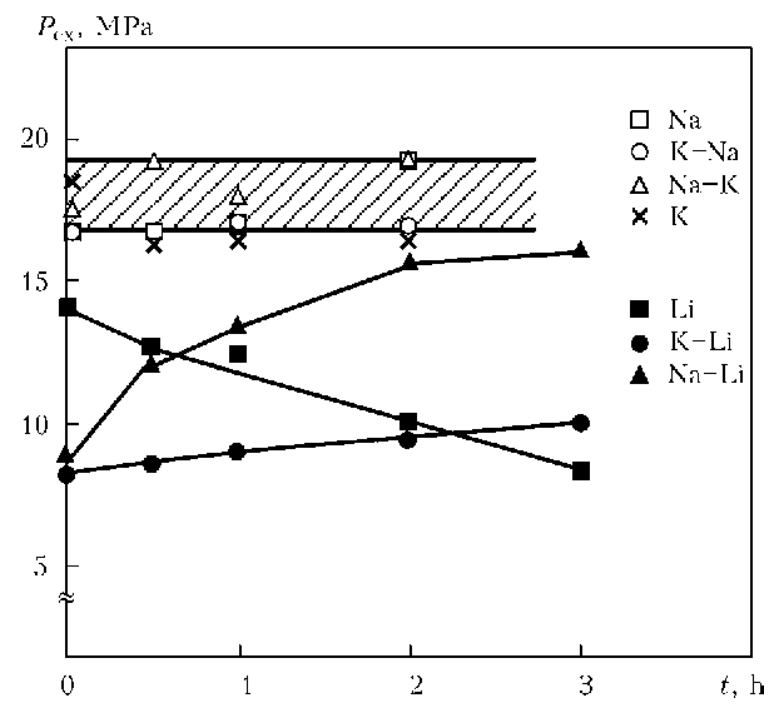

Figure 2. Change of extrusion pressure of ANBO electrode coating mixture made with different binders with time at $Q=1 \mathrm{~cm}^{3} / \mathrm{s}$ and $4.0 / 40 \mathrm{die}$ 


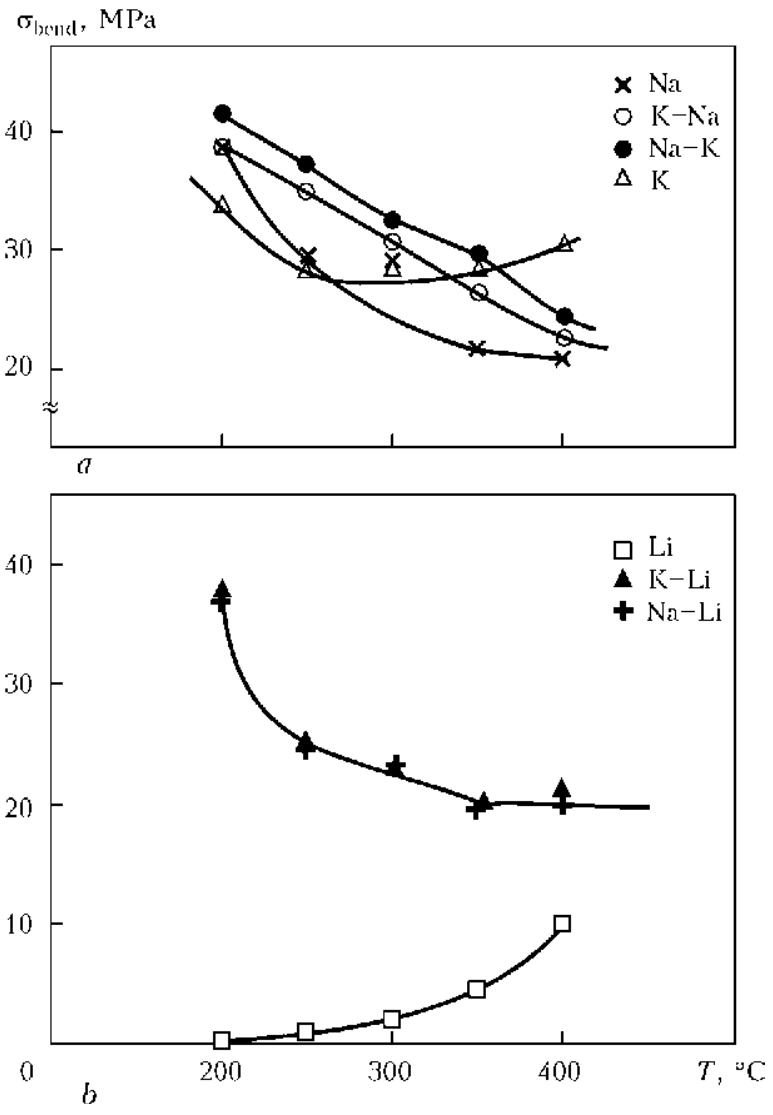

Figure 3. Dependencies of bending strength on baking temperature of ANBO electrodes coating mixture made with different binder types

with purely lithium binder, a noticeable «thinning» in time is observed as a result of interaction with fluorides contained in the coating mixture: extrusion pressure drops by $40 \%$ after $3 \mathrm{~h}$ of storage. At application of $\mathrm{K}-\mathrm{Li}$ liquid glass the coating mixture only slightly changes its consistency during the controlled time. At the same time, application of $\mathrm{Na}-\mathrm{Li}$ liquid glass causes hardening of coating mixture. Here, extrusion pressure rises by $50 \%$ within $3 \mathrm{~h}$, that is indicative of chemical reaction running in the coating mixture.

Coating mixture strength. Coating mechanical strength was evaluated by bending strength of $4 \mathrm{~mm}$ cylindrical samples of coating mixture baked at different temperatures, which were obtained by extrusion in capillary viscosimeter OB1453. Strength was determined by three-point bending method in a special attachment, developed at PWI, for conical autoplastometer. Test results are given in Figure 3.

It follows from the obtained data that strength of coating mixtures of electrodes for welding tin bronzes depends on binder kind and sample baking temperature. Similar to the case of coating mixture fluidity, bending strengths of coating mixtures made from $\mathrm{Na}-\mathrm{K}$ liquid glasses, on the whole, differ only slightly from each other in the entire range of studied baking temperatures. Here, strength decreases with increase of baking temperature. A certain difference is observed only at application of potassium binder: coating mixture strength is somewhat lower at the lowest baking temperature $\left(200{ }^{\circ} \mathrm{C}\right)$ and is the highest at maximum temperature $\left(400{ }^{\circ} \mathrm{C}\right)$. In the temperature range of $300-350{ }^{\circ} \mathrm{C}$ characteristic for heat treatment of electrodes for welding bronzes, coating mixture strength is practically equivalent for all $\mathrm{Na}-\mathrm{K}$ binders.

$\mathrm{Na}-\mathrm{Li}$ and $\mathrm{K}-\mathrm{Li}$ binders provide the same level of coating mixture strength, somewhat lower compared to $\mathrm{Na}-\mathrm{K}$ liquid glass (Figure $3, b$ ).

Lithium binder behaves differently from other studied binders. Coating mixture with this binder is characterized by a quite low level of strength with increase of baking temperature, that does not occur at application of other binders.

Electrode coating hygroscopicity. Atmospheric moisture absorption by electrode coatings has an adverse impact on quality of electrodes and welds. The main cause for coating hygroscopicity is the dry residue of binder in the coating: alkali silicate, determined by its composition and characteristics. Hygroscopicity was assessed by kinetics of moisture sorption by coating of electrodes baked in the chamber furnace at $300{ }^{\circ} \mathrm{C}$ in a hydrostat with $84 \%$ relative humidity at room temperature. Two test cycles were performed: with short- ( 8 h) and long-term (2 weeks) exposure. The results are given in Figure 4.

It is seen that the kind of binding has an essential influence on hygrosorption resistance of coatings of electrodes for bronze welding. Regularities of moisture absorption by coatings, made with $\mathrm{Na}-\mathrm{K}$ binders, are similar to those of electrodes for steel welding. The highest hygrosorption resistance is found in coatings with $\mathrm{Na}$ and $\mathrm{Na}-\mathrm{K}$ binders, and the lowest - with $\mathrm{K}$ and $\mathrm{K}-\mathrm{Na}$ binder. Level of moisture absorption by the coating is quite high: during $8 \mathrm{~h}$ the coatings absorb $0.6-0.8 \%$ of moisture at application of $\mathrm{Na}$ and $\mathrm{Na}-\mathrm{K}$ binders and about $1.1 \%$ for $\mathrm{K}$ and $\mathrm{K}-\mathrm{Na}$ binders; during 14 days moisture absorption reaches from 1.8 up to $3.3 \%$ for all the binders (Figure 4, $a, b$ ).

Li-containing binders in coatings of electrodes for bronze welding manifest an effect opposite to that in coatings of electrodes for steel welding. Increase of coating hygroscopicity to the level close to coatings with potassium and potassium-sodium silicates is observed (Figure 4, $c, d$ ). Coating with pure lithium silicate is characterized by the highest level of moisture sorption. Such an influence is, probably, related to interaction of $\mathrm{Li}$-containing binders with sodium fluoride compounds present in the charge, during coating mixture preparation. As a result, lithium cation from liquid glass is bound into practically insoluble lithium fluoride and lithium is substituted by sodium in the silicate.

Welding technological properties of electrodes. Welding-technological properties of elec- 

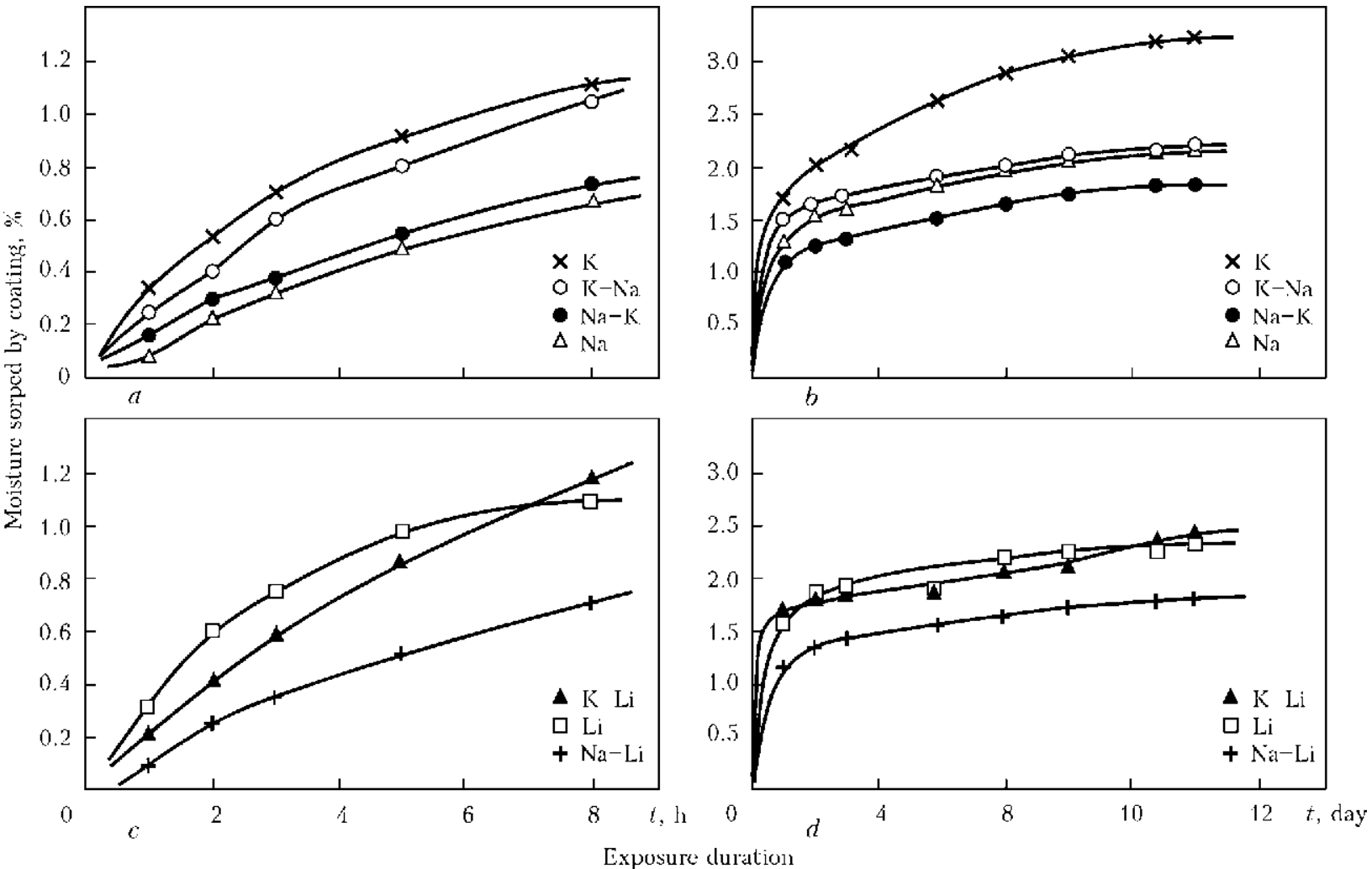

Figure 4. Kinetics of moisture sorption by coating of $4 \mathrm{~mm}$ ANBO electrodes manufactured with application of different binder types: $\mathrm{Na}-\mathrm{K}(a, b)$ and Li-containing $(c, d)$ at short- $(a, b)$ and long-term $(c, d)$ exposure at relative humidity of $84 \%$ and $20-23{ }^{\circ} \mathrm{C}$

trodes were assessed by the procedure of point ranging $[7,8]$ of welding process and weld formation. Some changes were made, because of specific requirements to application of ANBO electrodes. For comparison, OZB-2M electrodes, manufactured by Company «Spetselektrod», and UTP-32 German electrodes were used as reference ones.

Arcing stability was evaluated with application of an automated system for diagnostics and monitoring of welding process parameters with subsequent program processing of investigation results. Investigation results are given in Table 3.

Analysis of welding-technological properties showed good arc excitation in surfacing with the studied electrodes, except for OZB-2M. Here, one can see that arc elasticity characteristics are the highest in UTP-32 electrodes that is, possibly, associated with higher coefficient of coating mixture, compared to OZB-2M and ANBO electrodes, made with application of different kinds of glass. Uniform distribution of peak values of voltage and current when studying all the electrodes is indicative of high arcing stability. Despite the fact that UTP-32 electrodes provide the best coverage, high spatter is observed here, and bead surface is coarse-rippled, particularly at deposition of the first layer on steel (Figure 5). At visual inspection of beads and transverse macrosections, pores were revealed at application of OZB-2M grade electrodes made with $\mathrm{K}$ and $\mathrm{K}-\mathrm{Na}$ liquid glasses. Proceeding from that, UTP-

Table 3. Welding-technological properties of coated electrodes

\begin{tabular}{||c|c|c|c|c|c|c|c|c|c|c||}
\hline \hline $\begin{array}{c}\text { Electrode } \\
\text { type }\end{array}$ & $\begin{array}{c}\text { Arc } \\
\text { excitation }\end{array}$ & $\begin{array}{c}\text { Weld } \\
\text { formation } \\
\text { quality }\end{array}$ & $\begin{array}{c}\text { Arcing } \\
\text { stability }\end{array}$ & $\begin{array}{c}\text { Arc } \\
\text { elasticity }\end{array}$ & $\begin{array}{c}\text { Slag } \\
\text { coverability }\end{array}$ & $\begin{array}{c}\text { Slag detach- } \\
\text { ability }\end{array}$ & $\begin{array}{c}\text { Nature of } \\
\text { coating } \\
\text { melting }\end{array}$ & $\begin{array}{c}\text { Weld metal } \\
\text { spattering }\end{array}$ & $\begin{array}{c}\text { Defects in } \\
\text { deposited } \\
\text { metal }\end{array}$ & $\begin{array}{c}\text { Total points } \\
\text { OZB-2M }\end{array}$ \\
\hline & 2 & 4 & 3 & 2 & 2 & 1 & 4 & 3 & 24 \\
\hline $\mathrm{Na}$ & 5 & 4 & 4 & 4 & 3 & 3 & 4 & 4 & 5 & 36 \\
\hline $\mathrm{K}$ & 5 & 4 & 4 & 3 & 3 & 3 & 5 & 5 & 2 & 34 \\
\hline $\mathrm{K}-\mathrm{Na}$ & 5 & 4 & 5 & 4 & 3 & 3 & 4 & 5 & 5 & 38 \\
\hline $\mathrm{Na}-\mathrm{K}$ & 4 & 5 & 5 & 4 & 3 & 3 & 4 & 5 & 5 & 38 \\
\hline $\mathrm{K}-\mathrm{Li}$ & 5 & 4 & 5 & 3 & 3 & 3 & 3 & 5 & 3 & 34 \\
\hline $\mathrm{Na}-\mathrm{Li}$ & 5 & 4 & 5 & 3 & 3 & 3 & 4 & 5 & 5 & 37 \\
\hline $\mathrm{Li}$ & 5 & 4 & 5 & 4 & 3 & 3 & 4 & 5 & 5 & 38 \\
\hline $\mathrm{UTP}-32$ & 5 & 3 & 5 & 5 & 5 & 4 & 5 & 3 & 5 & 40 \\
\hline
\end{tabular}



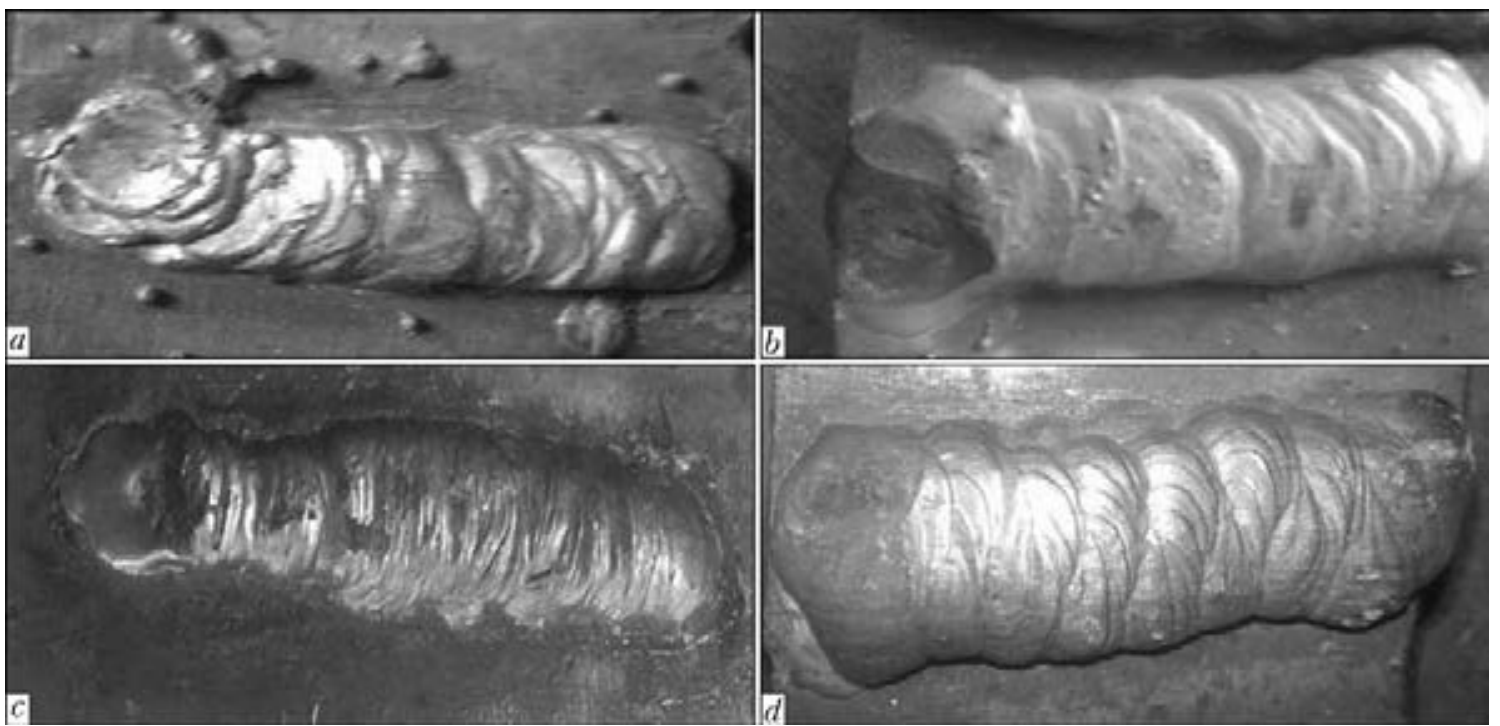

Figure 5. Appearance of deposited metal: $a$ - UTP-32 electrode, single-layer deposit; $b$ - UTP-32 electrode, three-layer deposit; $c$ - electrode based on $\mathrm{Na}-\mathrm{K}$ glass, single-layer deposit; $d$ - electrode based on $\mathrm{Na}-\mathrm{K}$ glass, three-layer deposit

Table 4. Sanitary-hygienic characteristics of electrodes for bronze welding ( $4 \mathrm{~mm}$ diameter, $I_{\mathrm{w}}=120-130 \mathrm{~A}, U_{\mathrm{a}}=23-25 \mathrm{~V}$ )

\begin{tabular}{|l|c|c||}
\hline \multicolumn{1}{|c|}{ Binder } & $V_{\text {SCWA }}, \mathrm{g} / \mathrm{min}$ & $G_{\text {SCWA }}, \mathrm{g} / \mathrm{kg}$ \\
\hline $\mathrm{Na}$ & 0.461 & 10.20 \\
\hline $\mathrm{Na}-\mathrm{K}$ & 0.404 & 9.13 \\
\hline $\mathrm{K}-\mathrm{Na}$ & 0.435 & 10 \\
\hline $\mathrm{K}$ & 0.493 & 11.29 \\
\hline $\mathrm{Na}-\mathrm{Li}$ & 0.393 & 8.71 \\
\hline $\mathrm{K}-\mathrm{Li}$ & 0.484 & 11.35 \\
\hline $\mathrm{Li}$ & 0.414 & 9.23 \\
\hline
\end{tabular}

32 electrodes, as well as electrodes made with $\mathrm{Li}, \mathrm{Na}-\mathrm{K}$ and $\mathrm{K}-\mathrm{Na}$ liquid glasses are the best in terms of welding-technological properties.

Sanitary-hygienic characteristics of electrodes. Sanitary-hygienic characteristics of electrodes were assessed by intensity of formation $V_{\mathrm{SCWA}}$ and specific evolution $G_{\mathrm{SCWA}}$ of the solid component of welding aerosol (SCWA). Determination of intensity of formation and specific evolution of SCWA was conducted by gravimetric method. Obtained results are presented in Table 4.

It is seen that the lowest levels of SCWA evolution are achieved in welding with electrodes made with application of Na-Li glasses $\left(V_{\mathrm{SCWA}}=\right.$ $\left.=0.393 \mathrm{~g} / \mathrm{min}, G_{\mathrm{SCWA}}=8.71 \mathrm{~g} / \mathrm{kg}\right)$. Electrodes based on $\mathrm{Na}-\mathrm{K}$ and $\mathrm{Li}$ binders are close to them as to SCWA evolution. The most favourable in terms of sanitary-hygienic characteristics are electrodes with $\mathrm{K}$ and $\mathrm{K}-\mathrm{Li}$ binders. So, for instance, the intensity of formation and specific evolutions in electrodes, made with $\mathrm{K}$ binder, are by 22.0 and $23.6 \%$ higher, respectively, than those in electrodes with $\mathrm{Na}-\mathrm{K}$ glass. Electrodes made with $\mathrm{K}-$ $\mathrm{Na}$ and $\mathrm{Na}$ binders, in terms of their sanitary-hygienic properties take an intermediate position between the two extreme electrode groups.

\section{Conclusion}

Procedure developed by PWI was used to study standard sodium, potassium and mixed sodiumpotassium and test lithium-containing liquid glasses, used in manufacture of electrodes for tin bronze welding and surfacing. As shown by comprehensive investigations of test electrode properties, the best results on adaptability to fabrication and welding-technological properties are ensured by sodium-potassium liquid binder.

1. Ilyushenko, V.M., Anoshin, V.A., Skorina, V.N. et al. (2013) Choice of slag-forming base of electrode coating for arc welding and surfacing of cast tin bronzes. In: Proc. of 7th Sci.-Techn. Conf. of Junior Scientists and Specialists (Kiev, 22-24 May 2013).

2. Ilyushenko, V.M., Anoshin, V.A., Bondarenko, A.N. et al. (2013) Development of electrode materials for welding and surfacing of complex-alloyed bronzes. In: Abstr. of Int. Conf. on Welding and Related Technologies: Present and Future (Kiev, 25-26 Nov. 2013), 72-73.

3. Skorina, N.V., Kisilyov, M.O., Paltsevich, A.P. et al. (2011) Properties of lithium-containing liquid glasses for manufacture of welding electrodes. In: Proc. of 4th Int. Conf. on Welding Consumables of CIS Countries (Krasnodar, 2011), 75-82.

4. Marchenko, A.E., Gnatenko, M.F., Chalykov, A.I. et al. (1983) Comparative evaluation of technological properties of electrode coating mixtures Rouen, Vitosha and YONI 13 made with capillary and conic plastometers: SMEA Inform. Doc., Issue 1/23, 6974. Kiev: Naukova Dumka.

5. Sokolov, V.A., Sotchenko, V.P., Marchenko, A.E. et al. (1981) Autoplastometer. Kiev: PWI.

6. Marchenko, A.E., Shkurko, S.A. (1975) Examination of electrode mixtures by capillary plastometer method. Svarochn. Proizvodstvo, 5, 11-13.

7. $R D$ 03-613-03: Procedure for application of welding consumables in manufacture, mounting, repair and reconstruction of technical devices for hazardous industrial facilities. Introd. 19.06.2003.

8. Ershov, A.V., Ershov, A.A. (2013) Welding-technological properties of electrodes used for welding of building metal structures. Svarka i Diagnostika, 3, 56-60. 